\title{
ANALISIS IDENTIFIKASI PRODUK UNGGULAN SUBSEKTOR TANAMAN PANGAN DI KABUPATEN JOMBANG
}

\author{
${ }^{1}$ Muhammad Rofiqul Farchan, ${ }^{2}$ Siti Nur Qomariah, ${ }^{3}$ Rohmat Hidayat \\ Program Studi Agribisnis, Fakultas Pertanian, Universitas KH. A. Wahab \\ Hasbullah \\ rofiq6648@gmail.com
}

\begin{abstract}
ABSTRAK
Penelitian ini bertujuan untuk mengetahui besaran kontribusi subsektor tanaman pangan terhadap sektor pertanian menjadi sektor basis dan jenis produk tanaman pangan yang merupakan produk unggulan di setiap Kecamatan di Kabupaten Jombang. Metode deskriptif digunakan untuk penelitian ini. dengan menggunakan metode analisis data Location Quotient. Data yang digunakan adalah data hasil produksi dan luas panen tanaman pangan di Kabupaten Jombang selama lima tahun (2014-2018), Produk Domestik Regional Bruto (PDRB) Provinsi Jawa Timur dan Kabupaten Jombang tahun 2014-2018 berdasarkan harga berlaku 2010 yang diperoleh dari BPS Provinsi Jawa Timur dan BPS Kabupaten Jombang. Hasil penelitian menunjukkan selama tahun 2014-2018, subsektor pertanian tanaman pangan di Kabupaten Jombang belum dapat dikategorikan sebagai subsektor basis, karena mempunyai nilai rata-rata $\mathrm{LQ}<1$ yaitu sebesar 0,96 persen. Berdasarkan PDRB kabupaten Jombang menurut harga berlaku, subsektor tanaman pangan mengalami penurunan dari tahun 2014 sampai di tahun 2018 sebesar 1,95 persen. Hasil identifikasi produk unggulan subsektor tanaman pangan dari setiap kecamatan, padi dan jagung mempunyai nilai paling unggul di bandingkan dengan jenis tanaman pangan lainnya.
\end{abstract}

Kata kunci: Tanaman Pangan, Locational Quotient, sektor basis

\section{PENDAHULUAN}

Sektor pertanian merupakan nilai komoditas-komoditas pertanian dari subsektor tanaman pangan, perkebunan, peternakan, kehutanan, perikanan, dan jasa pertanian yang diakumulasi menjadi total output sektor pertanian. Sektor pertanian mampu berperan dalam peningkatan ketersediaan pangan dan pendapatan melalui kegiatan perdagangan. Pertanian juga dipandang sebagai suatu sektor yang memiliki kemampuan khusus dalam memadukan pertumbuhan dan pemerataan (growth with aquity) atau pertumbuhan yang berkualitas di suatu wilayah, salah satunya ada di Kabupaten Jombang. Wilayah tersebut masih menitikberatkan pada kegiatan sector pertanian karena mempunyai keunggulan dalam pemenuhan kebutuhan pangan dan perekonomiannya. Oleh karena itu dengan mengarahkan potensi untuk mengembangkan wilayah di 5 sektor unggulan, salah satunya di sector pertanian.

Adanya otonomi daerah menjadi langkah awal suatu daerah untuk mengembangkan potensi wilayah yang dimiliki sehingga tercipta pertumbuhan (Sofyan, 2014). Salah satu cara untuk meningkatkan pertumbuhan potensi di Kabupaten Jombang adalah dengan menentukan komoditas yang menjadi sector penggerak ekonomi suatu wilayah, untuk dikembangkan menjadi sector unggulan untuk peningkatan pembangunan daerah. Sektor unggulan ini perlu ditentukan 
oleh suatu daerah karena setiap daerah mempunyai karakter yang berbeda dari sisi kesuburan tanah, letak geografis, sumber daya manusia, sarana dan prasarana yang ada (Hardyanto, 2014). Oleh karena itu mengingat di suatu daerah tidak semua sector dapat menjadi unggulan, maka pemerintah perlu membuat strategi pembangunan berdasarkan preferensi agar kebijakan pembangunan di daerah mampu berjalan optimal.

Komoditi unggulan dapat diartikan sebagai komoditi yang mempunyai nilai tambah dan produksi terbesar sehingga mampu mendorong peningkatan pertumbuhan ekonomi daerah. Di Kabupaten Jombang, komoditi Tanaman pangan yang dibudidayakan terdiri dari tanaman pangan dan palawija. Tanaman pangan yaitu padi, dan jagung, sedangkan tanaman palawija terdiri dari kacang tanah, kacang hijau, kedelai, ubi kayu dan ubi jalar(BPS, 2018). Hal tersebut didukung dengan penggunaan lahan di Kabupaten Jombang berdasarkan kawasan budidaya pertanian yang terdiri dari 2 bagian, yaitu lahan sawah dan non sawah. Berdasarkan Badan Pusat Statistik Kabupaten Jombang Tahun 2018, luas lahan untuk kegiatan pertanian mencapai $86,54 \%$ dan lahan bukan pertanian 13,46 persen dari luas wilayah kabupaten Jombang yaitu $115.950 \mathrm{Ha}$.

Peranan pertanian tanaman pangan yang relatif besar tersebut di sebabkan karena kondisi di Kabupaten Jombang mempunyai potensi untuk di kembangkannya komoditi-komiditi tanaman pangan. Berdasarkan potensi tersebut, maka dapat di jadikan sebagai penunjang ketersediaan setiap komoditi terutama tanaman pangan. Hal ini disebabkan komoditi tanaman pangan merupakan komoditi kebutuhan pokok yang dikonsumsi di setiap daerah sehingga mempunyai prospek yang bagus untuk dikembangkan dan mampu dipertahankan posisinya dari komoditi-komoditi tanaman pangan, terutama komoditi yang sudah mempunyai sentra sebagai komoditi unggulan. Jumlah produksi dari setiap komoditi ini nantinya akan menentukan berapa nilai produksi yang mampu di hasilkannya (dinas Pertanian Kabupaten Jombang). Oleh karena itu perlu dilakukan pengkajian tentang Analisa Identifikasi Produk Unggulan Subsektor Tanaman Pangan di Kabupaten Jombang.

\section{METODOLOGI PENELITIAN}

Tempat dan Waktu Penelitian. pelaksanaan penelitian dikerjakan di Kabupaten Jombang, Provinsi Jawa Timur, pada bulan April sampai dengan Juni 2020. Pertimbangan penelitian di lakukan di Kabupaten Jombang, agar hasilnya menjadi bahan informasi dan preferensi pada perencanaan pembangunan di Kabupaten Jombang tentang sektor ungggulan pertanian. Adapun jenis penelitian yang digunakan adalah metode deskriptif dengan penggunaan data sekunder.

Jenis dan Sumber Data. Data sekunder diperoleh dari data terkait yaitu Badan Pusat Statistik (BPS) Kabupaten Jombang dan Dinas Pertanian Kabupaten Jombang , serta sumber publikasi yang dibutuhkan untuk mengukur nilai basis serta faktor-faktor yang berpengaruh terhadap sub sektor tanaman pangan periode tahun 2014-2018 pada setiap kecamatan di kabupaten Jombang. .Sumber data yang digunakan dalam penulisan ini antara lain berasal dari Badan Pusat Statistik Kabupaten Jombang, Dinas Pertanian Kabupaten Jombang, bukubuku dan jurnal-jurnal.

Metode Pengumpulan Data. Metode dokumentasi digunakan untuk teknik pengumpulan data pada penelitian ini, yaitu berupa data sekunder yang di peroleh dari BPS Kabupaten Jombang dan Dinas Pertanian Kabupaten Jombang.

Analisis Data. Analisis data menggunakan Analisis Location Quotient (LQ), 
digunakan untuk menentukan atau mencari jenis produksi unggulan pertanian melalui hasil pengambilan data Produk Domestik Regional Bruto tahun 20142018. Alat analisis $L Q$ ini dapat melihat komoditas apa saja yang menjadi unggulan di Kabupaten Jombang (wilayah studi) di bandingkan dengan Provinsi Jawa Timur (wilayah referensi). Adapun Rumus LQ (Tanjung, 2017) di bawah ini:

Dimana :

$$
L Q=\frac{L i / L t}{P i / P t}
$$

(LQ) di rumuskan sebagai.

$\mathrm{Li} \quad=$ Jumlah produksi di Kecamatan.

Lt $\quad=$ Total jumlah produksi di Kabupaten Jombang.

$\mathrm{Pi} \quad=$ Jumlah produksi komoditas di Kecamatan.

$\mathrm{Pt} \quad=$ Total jumlah produksi subsektor pertanian di Kabupaten Jombang.

Kriteria nilai LQ hasil penghitungan di peroleh kategori sebagai berikut:

1. Apabila nilai LQ suatu komoditas $>1$, maka komoditas tersebut dapat di katakan sebagai komoditas unggulan.

2. Apabila nilai LQ suatu komoditas $<1$, maka komoditas tersebut dapat di katakan sebagai bukan komoditas unggulan.

3. Apabila nilai LQ suatu komoditas $=1$, maka komoditas tersebut dapat di katakan komoditas yang hanya dapat memenuhi kebutuahan daerahnya sendiri.

\section{HASIL DAN PEMBAHASAN}

Kontribusi Subsektor Tanaman Pangan. Di Kabupaten Jombang, pertanian menjadi sector yang dapat menyangga ekonomi masyarakatnya.. Hal ini ditunjukkan dengan cukup besarnya peranan sektor pertanian terhadap Nilai Tambah Kategori Pertanian sebesar 94,91 di tahun 2014 (Tabel 1). Nilai tersebut kemudian mengalami pergerakan naik turun setiap tahunnya hingga tahun 2018, yang diikuti dengan naik turunnya masing - masing subsektor pertanian. Terdapat kecenderungan penurunan kontribusi dari peranan subsektor tanaman pangan pada peranan Subkategori kontribusi di subsektor Pertanian, Peternakan, Perburuan dan Jasa Pertanian. Tabel 1 menunjukkan persentase penurunan kontribusi terjadi pada tahun 2014 yaitu 41,77, sampai pada tahun 2018 yaitu 39,82 di Kabupaten Jombang Salah satu faktor penyebab penurunan kontribusi subsektor tersebut adalah situasi cuaca yang sulit diprediksi dan kondisi iklim yang ekstrim, sehingga menimbulkan kegagalan panen pada pertanian tanaman pangan.

Tabel 1. Peranan Subkategori terhadap Nilai Tambah Kategori Pertanian, Peternakan, Perburuan, dan Jasa Pertanian di Kabupaten Jombang Harga Berlaku (Persen), 2014-2018.

\begin{tabular}{llllll}
\hline Lapangan Usaha & 2014 & 2015 & 2016 & 2017 & 2018 \\
\hline 1. Pertanian, Peternakan, Perburuan & 94,91 & 94,79 & 94,98 & 94,72 & 94,63 \\
danJasa Pertanian & 41,77 & 42,17 & 41,55 & 39,57 & 39,82 \\
$\quad$ a. TanamanPangan & 1,81 & 1,78 & 1,85 & 1,89 & 1,90 \\
$\quad$ b. TanamanHortikultura & 13,35 & 13,10 & 13,08 & 13,23 & 12,69 \\
$\quad$ c. TanamanPerkebunan & 41,62 & 41,42 & 41,96 & 43,72 & 44,03 \\
$\quad$ d.Peternakan & 1,46 & 1,53 & 1,57 & 1,58 & 1,56
\end{tabular}




\begin{tabular}{|c|c|c|c|c|c|c|}
\hline $\begin{array}{ll}\text { 2. } & \text { Kehutanan } \\
\text { 3. } & \text { Perikanan }\end{array}$ & bangan & $\begin{array}{l}3,49 \\
1,60\end{array}$ & $\begin{array}{l}3,61 \\
1,59\end{array}$ & $\begin{array}{l}3,39 \\
1,63\end{array}$ & $\begin{array}{l}3,56 \\
1,72\end{array}$ & $\begin{array}{l}3,61 \\
1,76\end{array}$ \\
\hline $\begin{array}{l}\text { Pertanian, } \\
\text { danPerikanan }\end{array}$ & Kehutanan, & 100,0 & 100,0 & 100,0 & 100,0 & 100,0 \\
\hline
\end{tabular}

Sumber: BPS Kabupaten Jombang, menurut harga berlaku diolah

Nilai LQ Pada Produk Domestik Regional Bruto (PDRB) Subsektor. Diketahui bahwa jika nilai LQ suatu subsektor > 1, dapat dinyatakan sektor tersebut adalah subsektor basis, dan apabila nilai $L Q$ suatu subsektor $<1$, berarti subsektor tersebut merupakan subsektor non basis. Berdasarkan data yang digunakan untuk mendapatkan nilai LQ subsector tanaman pangan di Kabupaten Jombang, maka rumusan untuk nilai LQ Pada Produk Domestik Regional Bruto (PDRB) Subsektor tersebut merupakan hasil dari pembagian PDRB subsektor pertanian Kabupaten Jombang(Li) dengan PDRB total daerah subsektor pertanian Kabupaten Jombang(Lt), yang dibagi hasil dari pembagian PDRB subsektor pertanian Provinsi Jawa Timur(Pi) dengan PDRB total daerah/sektor pertanian Provinsi Jawa Tmur(Pt).

Berdasarkan tabel 2 diketahui, Nilai LQ PDRB subsektor atas harga berlaku menurut lapangan usaha 2014-2018 Kabupaten Jombang. Nilai tersebut menunjukan hasil penghitungan LQ subkategori pertanian di Kabupaten Jombang menurut PDRB atas dasar harga berlaku tahun 2014-2018, tanaman pangan belum menjadi sektor basis. Hal ini disebabkan karena LQ tanaman pangan rata-rata belum mencapai angka satu. Sejak tahun 2014 sampai 2018 nilai LQ tanaman pangan belum mencapai angka satu atau lebih dari satu. Rata rata LQ dari tahun 2014-2018 hanya mencapai 0,96 . Kategori yang sama juga diperoleh dari nilai LQ tanaman hortikultura, tanaman perkebunan dan jasa pertanian dan pemburuhan yang belum dapat menjadi sektor basis. Oleh karena itu menurut penghitungan $L Q$, apabila $L Q$ belum mencapai angka satu maka belum dinyatakan unggul atau basis.

Berdasarkan hasil penghitungan, rata rata nilai LQ sektor peternakan mencapai 4,17 . Hal ini menunjukkan bahwa yang nilai $L Q$ sektor tersebut lebih dari satu, sehingga dapat dinyatakan bahwa sektor peternakan Kabupaten Jombang dari tahun 2014 sampai dengan 2018 adalah unggul atau basis. Meskipun dari tahun 2014 sampai tahun 2018 nilai LQ sektor peternakan mengalami penurunan, sektor peternakan tetap menjadi sektor basis karena sektor tersebut menjadi penyumbang terbesar PDRB Jawa Timur.

Tabel 2. Nilai LQ PDRB sub sektor atas harga berlaku menurut lapangan usaha , 2014-2018 Kabupaten Jombang.

\begin{tabular}{|c|c|c|c|c|c|c|c|}
\hline LQ & 2014 & 2015 & 2016 & 2017 & 2018 & $\begin{array}{l}\text { RATA- } \\
\text { RATA }\end{array}$ & KETERANGAN \\
\hline a. Tanaman Pangan & 0,97 & 0,97 & 0,99 & 0,94 & 0,92 & 0,96 & Non Basis \\
\hline b. Tanaman Hortikultura & 0,16 & 0,15 & 0,16 & 0,15 & 0,15 & 0,15 & Non Basis \\
\hline c. Tanaman Perkebunan & 0,63 & 0,63 & 0,68 & 0,65 & 0,63 & 0,64 & Non Basis \\
\hline d. Peternakan & 4,86 & 4,75 & 1,63 & 4,82 & 4,78 & 4,17 & Basis \\
\hline $\begin{array}{l}\text { e. Jasa Pertanian dan } \\
\text { Perburuhan }\end{array}$ & 0,09 & 0,10 & 1,11 & 0,10 & 0,11 & 0,30 & Non Basis \\
\hline
\end{tabular}

Sumber : Analisis Data Sekunder (olahan).

Menentukan Produk Unggulan Tanaman Pangan di Kabupaten Jombang. Nilai LQ Berdasarkan Hasil Panen (Ha) dan Produksi (Ton) rata-rata pada 
tanaman pangan per Kecamatan pada tahun 2014-2018 ditunjukkan pada tabel 3.

Tabel 3. Nilai LQ Berdasarkan Luas Panen (Ha) dan Produksi (Ton) rerata pada tanaman pangan per Kecamatan di Kabupaten Jombang pada tahun 2014-2018.

\begin{tabular}{|c|c|c|c|c|c|c|c|c|c|c|c|c|c|c|}
\hline \multirow{2}{*}{$\begin{array}{l}\text { Kecamata } \\
\text { n }\end{array}$} & \multicolumn{7}{|c|}{ Luas Panen } & \multicolumn{7}{|c|}{ Produksi } \\
\hline & JG & PD & KD & KT & $\mathbf{K H}$ & UJ & UK & JG & PD & KD & KT & $\mathbf{K H}$ & UJ & UK \\
\hline $\begin{array}{l}\text { Bandar } \\
\text { KM }\end{array}$ & $\begin{array}{l}0,8 \\
3\end{array}$ & $\begin{array}{l}1,1 \\
5\end{array}$ & - & $\begin{array}{l}0,3 \\
1\end{array}$ & - & - & - & $\begin{array}{l}0,8 \\
7\end{array}$ & $\begin{array}{l}1,1 \\
2\end{array}$ & - & $\begin{array}{l}0,3 \\
1\end{array}$ & - & - & - \\
\hline Perak & $\begin{array}{l}0,5 \\
4\end{array}$ & $\begin{array}{l}1,2 \\
8\end{array}$ & $\begin{array}{l}0,0 \\
0\end{array}$ & $\begin{array}{l}0,3 \\
9\end{array}$ & $\begin{array}{l}0,3 \\
3\end{array}$ & $\begin{array}{l}1,4 \\
0\end{array}$ & $\begin{array}{l}0,3 \\
6\end{array}$ & $\begin{array}{l}0,5 \\
8\end{array}$ & $\begin{array}{l}1,2 \\
6\end{array}$ & $\begin{array}{l}0,0 \\
0\end{array}$ & $\begin{array}{l}0,3 \\
9\end{array}$ & $\begin{array}{l}0,3 \\
9\end{array}$ & $\begin{array}{l}1,3 \\
9\end{array}$ & $\begin{array}{l}0,1 \\
6\end{array}$ \\
\hline Gudo & $\begin{array}{l}1,0 \\
3\end{array}$ & $\begin{array}{l}1,0 \\
6\end{array}$ & $\begin{array}{l}0,0 \\
0\end{array}$ & $\begin{array}{l}0,2 \\
2\end{array}$ & - & $\begin{array}{l}0,0 \\
7\end{array}$ & - & $\begin{array}{l}0,9 \\
2\end{array}$ & $\begin{array}{l}1,1 \\
1\end{array}$ & $\begin{array}{l}0,0 \\
0\end{array}$ & $\begin{array}{l}0,2 \\
2\end{array}$ & - & $\begin{array}{l}0,0 \\
8\end{array}$ & - \\
\hline Diwek & $\begin{array}{l}1,4 \\
6\end{array}$ & $\begin{array}{l}0,8 \\
1\end{array}$ & $\begin{array}{l}0,1 \\
9\end{array}$ & $\begin{array}{l}6,1 \\
2\end{array}$ & $\begin{array}{l}0,3 \\
7\end{array}$ & $\begin{array}{l}0,2 \\
5\end{array}$ & $\begin{array}{l}0,1 \\
3\end{array}$ & $\begin{array}{l}1,4 \\
5\end{array}$ & $\begin{array}{l}0,8 \\
0\end{array}$ & $\begin{array}{l}0,1 \\
9\end{array}$ & $\begin{array}{l}5,9 \\
3\end{array}$ & $\begin{array}{l}0,3 \\
3\end{array}$ & $\begin{array}{l}0,9 \\
6\end{array}$ & $\begin{array}{l}0,1 \\
3\end{array}$ \\
\hline Ngoro & $\begin{array}{l}0,9 \\
4\end{array}$ & $\begin{array}{l}1,0 \\
4\end{array}$ & - & $\begin{array}{l}0,5 \\
5\end{array}$ & - & $\begin{array}{l}14 \\
9\end{array}$ & $\begin{array}{l}5,7 \\
4\end{array}$ & $\begin{array}{l}0,9 \\
1\end{array}$ & $\begin{array}{l}0,9 \\
7\end{array}$ & - & $\begin{array}{l}0,5 \\
2\end{array}$ & - & $\begin{array}{l}13 \\
2\end{array}$ & $\begin{array}{l}3,0 \\
1\end{array}$ \\
\hline $\begin{array}{l}\text { Mojowarn } \\
\text { o }\end{array}$ & $\begin{array}{l}1,2 \\
1\end{array}$ & $\begin{array}{l}0,9 \\
5\end{array}$ & $\begin{array}{l}0,4 \\
0\end{array}$ & $\begin{array}{l}0,3 \\
8\end{array}$ & $\begin{array}{l}0,5 \\
9\end{array}$ & - & $\begin{array}{l}0,0 \\
3\end{array}$ & $\begin{array}{l}1,2 \\
8\end{array}$ & $\begin{array}{l}0,9 \\
1\end{array}$ & $\begin{array}{l}0,3 \\
5\end{array}$ & $\begin{array}{l}0,3 \\
4\end{array}$ & $\begin{array}{l}0,5 \\
2\end{array}$ & - & $\begin{array}{l}0,0 \\
3\end{array}$ \\
\hline Bareng & $\begin{array}{l}0,8 \\
2\end{array}$ & $\begin{array}{l}1,0 \\
9\end{array}$ & $\begin{array}{l}0,5 \\
3\end{array}$ & $\begin{array}{l}0,0 \\
8\end{array}$ & $\begin{array}{l}1,2 \\
9\end{array}$ & $\begin{array}{l}0,3 \\
8\end{array}$ & $\begin{array}{l}2,0 \\
2\end{array}$ & $\begin{array}{l}0,7 \\
9\end{array}$ & $\begin{array}{l}1,0 \\
5\end{array}$ & $\begin{array}{l}0,5 \\
0\end{array}$ & $\begin{array}{l}0,0 \\
8\end{array}$ & $\begin{array}{l}1,5 \\
3\end{array}$ & $\begin{array}{l}0,5 \\
6\end{array}$ & $\begin{array}{l}2,4 \\
9\end{array}$ \\
\hline $\begin{array}{l}\text { Wonosala } \\
\text { m }\end{array}$ & $\begin{array}{l}2,4 \\
6\end{array}$ & $\begin{array}{l}0,2 \\
4\end{array}$ & - & $\begin{array}{l}0,1 \\
4\end{array}$ & - & $\begin{array}{l}0,6 \\
1\end{array}$ & $\begin{array}{l}14 \\
2\end{array}$ & $\begin{array}{l}1,7 \\
8\end{array}$ & $\begin{array}{l}0,1 \\
9\end{array}$ & - & $\begin{array}{l}0,1 \\
2\end{array}$ & - & $\begin{array}{l}0,6 \\
0\end{array}$ & $\begin{array}{l}13, \\
3\end{array}$ \\
\hline $\begin{array}{l}\text { Mojoagun } \\
\text { g }\end{array}$ & $\begin{array}{l}1,1 \\
0\end{array}$ & $\begin{array}{l}0,9 \\
5\end{array}$ & $\begin{array}{l}1,3 \\
1\end{array}$ & $\begin{array}{l}0,1 \\
9\end{array}$ & $\begin{array}{l}11 \\
7\end{array}$ & - & - & $\begin{array}{l}1,1 \\
8\end{array}$ & $\begin{array}{l}0,9 \\
4\end{array}$ & $\begin{array}{l}1,2 \\
6\end{array}$ & $\begin{array}{l}0,2 \\
0\end{array}$ & $\begin{array}{l}11 \\
4\end{array}$ & - & - \\
\hline Sumobito & $\begin{array}{l}0,9 \\
7\end{array}$ & $\begin{array}{l}0,9 \\
8\end{array}$ & $\begin{array}{l}2,0 \\
5\end{array}$ & - & - & - & - & $\begin{array}{l}1,0 \\
4\end{array}$ & $\begin{array}{l}1,0 \\
0\end{array}$ & $\begin{array}{l}2,0 \\
0\end{array}$ & - & - & - & - \\
\hline Jogoroto & $\begin{array}{l}1,7 \\
3\end{array}$ & $\begin{array}{l}0,6 \\
9\end{array}$ & $\begin{array}{l}0,3 \\
7\end{array}$ & $\begin{array}{l}4,3 \\
0\end{array}$ & $\begin{array}{l}1,0 \\
0\end{array}$ & - & $\begin{array}{l}0,0 \\
2\end{array}$ & $\begin{array}{l}1,7 \\
0\end{array}$ & $\begin{array}{l}0,6 \\
8\end{array}$ & $\begin{array}{l}0,3 \\
7\end{array}$ & $\begin{array}{l}4,1 \\
2\end{array}$ & $\begin{array}{l}1,0 \\
0\end{array}$ & - & $\begin{array}{l}0,0 \\
2\end{array}$ \\
\hline $\begin{array}{l}\text { Peteronga } \\
\mathbf{n}\end{array}$ & $\begin{array}{l}0,9 \\
6\end{array}$ & $\begin{array}{l}0,9 \\
8\end{array}$ & $\begin{array}{l}1,8 \\
3\end{array}$ & $\begin{array}{l}0,3 \\
8\end{array}$ & $\begin{array}{l}0,4 \\
4\end{array}$ & - & - & $\begin{array}{l}0,9 \\
7\end{array}$ & $\begin{array}{l}1,0 \\
4\end{array}$ & $\begin{array}{l}2,0 \\
2\end{array}$ & $\begin{array}{l}0,3 \\
9\end{array}$ & $\begin{array}{l}0,3 \\
9\end{array}$ & - & - \\
\hline Jombang & $\begin{array}{l}0,8 \\
1\end{array}$ & $\begin{array}{l}1,1 \\
2\end{array}$ & $\begin{array}{l}0,1 \\
8\end{array}$ & $\begin{array}{l}6,1 \\
9\end{array}$ & - & - & $\begin{array}{l}0,0 \\
3\end{array}$ & $\begin{array}{l}0,8 \\
9\end{array}$ & $\begin{array}{l}1,1 \\
0\end{array}$ & $\begin{array}{l}0,1 \\
9\end{array}$ & $\begin{array}{l}6,3 \\
1\end{array}$ & - & - & $\begin{array}{l}0,0 \\
2\end{array}$ \\
\hline Megaluh & $\begin{array}{l}0,2 \\
4\end{array}$ & $\begin{array}{l}1,4 \\
1\end{array}$ & - & $\begin{array}{l}1,6 \\
8\end{array}$ & - & - & - & $\begin{array}{l}0,2 \\
5\end{array}$ & $\begin{array}{l}1,4 \\
4\end{array}$ & - & $\begin{array}{l}1,7 \\
6\end{array}$ & - & - & - \\
\hline $\begin{array}{l}\text { Tembelan } \\
\text { g }\end{array}$ & $\begin{array}{l}0,4 \\
0\end{array}$ & $\begin{array}{l}1,0 \\
7\end{array}$ & $\begin{array}{l}5,0 \\
4\end{array}$ & $\begin{array}{l}0,6 \\
1\end{array}$ & $\begin{array}{l}0,9 \\
1\end{array}$ & - & $\begin{array}{l}0,0 \\
8\end{array}$ & $\begin{array}{l}0,4 \\
9\end{array}$ & & $\begin{array}{l}5,3 \\
9\end{array}$ & $\begin{array}{l}0,6 \\
9\end{array}$ & $\begin{array}{l}1,0 \\
7\end{array}$ & - & $\begin{array}{l}0,1 \\
1\end{array}$ \\
\hline Kesamben & $\begin{array}{l}0,3 \\
4\end{array}$ & $\begin{array}{l}1,1 \\
4\end{array}$ & $\begin{array}{l}4,4 \\
4\end{array}$ & - & - & - & - & $\begin{array}{l}0,3 \\
8\end{array}$ & $\begin{array}{l}1,3 \\
0\end{array}$ & $\begin{array}{l}5,0 \\
2\end{array}$ & - & - & - & - \\
\hline Kudu & $\begin{array}{l}0,9 \\
8\end{array}$ & $\begin{array}{l}0,8 \\
4\end{array}$ & $\begin{array}{l}0,8 \\
9\end{array}$ & $\begin{array}{l}0,2 \\
5\end{array}$ & $\begin{array}{l}0,3 \\
5\end{array}$ & - & - & $\begin{array}{l}1,0 \\
0\end{array}$ & $\begin{array}{l}0,8 \\
4\end{array}$ & $\begin{array}{l}0,9 \\
3\end{array}$ & $\begin{array}{l}0,2 \\
6\end{array}$ & $\begin{array}{l}0,3 \\
0\end{array}$ & - & - \\
\hline Ngusikan & $\begin{array}{l}1,4 \\
3\end{array}$ & $\begin{array}{l}0,8 \\
1\end{array}$ & $\begin{array}{l}1,4 \\
4\end{array}$ & - & $\begin{array}{l}0,0 \\
7\end{array}$ & - & - & $\begin{array}{l}1,3 \\
7\end{array}$ & $\begin{array}{l}0,8 \\
4\end{array}$ & $\begin{array}{l}1,4 \\
6\end{array}$ & - & $\begin{array}{l}0,0 \\
6\end{array}$ & - & - \\
\hline Ploso & $\begin{array}{l}0,3 \\
8\end{array}$ & $\begin{array}{l}1,3 \\
5\end{array}$ & $\begin{array}{l}0,0 \\
9\end{array}$ & $\begin{array}{l}0,1 \\
0\end{array}$ & - & - & - & $\begin{array}{l}0,4 \\
3\end{array}$ & $\begin{array}{l}1,3 \\
6\end{array}$ & $\begin{array}{l}0,0 \\
9\end{array}$ & $\begin{array}{l}0,0 \\
9\end{array}$ & - & - & - \\
\hline Kabuh & $\begin{array}{l}1,6 \\
2\end{array}$ & $\begin{array}{l}0,8 \\
0\end{array}$ & $\begin{array}{l}0,0 \\
4\end{array}$ & $\begin{array}{l}0,0 \\
6\end{array}$ & $\begin{array}{l}0,0 \\
8\end{array}$ & - & $\begin{array}{l}0,0 \\
4\end{array}$ & $\begin{array}{l}1,4 \\
7\end{array}$ & $\begin{array}{l}0,8 \\
2\end{array}$ & $\begin{array}{l}0,0 \\
4\end{array}$ & $\begin{array}{l}0,0 \\
6\end{array}$ & $\begin{array}{l}0,0 \\
8\end{array}$ & - & $\begin{array}{l}0,0 \\
2\end{array}$ \\
\hline Plandaan & $\begin{array}{l}0,7 \\
9\end{array}$ & $\begin{array}{l}1,1 \\
4\end{array}$ & $\begin{array}{l}0,8 \\
2\end{array}$ & $\begin{array}{l}0,7 \\
1\end{array}$ & - & - & $\begin{array}{l}0,0 \\
5\end{array}$ & $\begin{array}{l}0,7 \\
6\end{array}$ & $\begin{array}{l}1,1 \\
6\end{array}$ & $\begin{array}{l}0,8 \\
6\end{array}$ & $\begin{array}{l}0,7 \\
2\end{array}$ & - & - & $\begin{array}{l}0,0 \\
4\end{array}$ \\
\hline
\end{tabular}

Sumber: Analisis Data Sekunder (olahan).

Keterangan : $\mathrm{JG}=$ jagung, $\mathrm{PD}=$ padi, $\mathrm{KD}=$ kedelai, $\mathrm{KT}=$ kacang tanah, $\mathrm{KH}=$ kacang hijau, UJ = ubi jalar, UK = ubi kayu

Berdasarkan tabel 3, menunjukkan nilai analisis LQ tanaman pangan berdasarkan luas panen (Ha) dan Produksi (Ton) di setiap kecamatan yang ada di Kabupaten Jombang mulai dari tahun 2014 sampai 2018. Diketahui kecamatan yang mempunyai nilai $L Q>1$ pada luas panen $(\mathrm{Ha})$ dan Produksi (ton) untuk jenis tanaman jagung diperoleh dari kecamatan Diwek, Mojowarno, Wonosalam, Mojoagung, Jogoroto, Ngusikan, dan Kabuh. Pada jenis tanaman padi dengan nilai $L Q>1$ diperoleh kecamatan Bandar Kedung Mulyo, Perak, Gudo, Bareng, Jombang, Megaluh, Tembelang, Kesamben, Ploso, dan Plandaan. Nilai LQ > 1 untuk tanaman jenis kedelai diperoleh di 5 kecamatan, yaitu Mojoagung, Sumobito, Peterongan, Tembelang, dan Ngusikan. Sedangkan kecamatan yang mempunyai nilai $L Q>1$ untuk jenis kacang tanah terdapat di Diwek, Jogoroto, 
Jombang, dan Megaluh. Nilai LQ yang > 1 berdasarkan Luas Panen $(\mathrm{Ha})$ dan Produksi (Ton) rata-rata untuk jenis tanaman kacang hijau hanya terdapat di 2 kecamatan, yaitu Bareng dan Mojoagung, begitu pula dengan jenis Ubi jalar, hanya diperoleh di kecamatan Perak dan Ngoro. Sedangkan tanaman jenis ubi kayu hanya ada di 3 kecamatan yang mempunyai nilai $L Q>1$ yaitu Ngoro, Bareng, dan Wonosalam.

Adanya nilai $L Q>1$ luas panen dan produksi pada jenis tanaman pangan di setiap kecamatan menunjukkan bahwa daerah mampu mencukupi kebutuhan dari jenis tanaman pangan tersebut. Selain itu daerah juga mampu untuk mengirimkan ke daerah lain untuk memenuhi kebutuhan jenis tanaman pangan yang diperlukan. Seperti pada jenis tanaman padi, terdapat 12 kecamatan di wilayah Kabupaten Jombang mempunyai nilai $L Q>1$ untuk luas panen dan produksinya. Oleh karena itu, 9 kecamatan yang mempunyai nilai $L Q<1$ dapat tercukupi kebutuhan komoditi dari tanaman padi oleh 12 kecamatan tersebut. Sedangkan jenis tanaman ubi jalar dan ubi kayu, kecamatan yang mempunyai nilai $L Q>1$ untuk luas panen dan produksi hanya ada di 2 dan 3 kecamatan. Bahkan di beberapa kecamatan tidak terdapat nilai LQ yang berarti banyak kecamatan tidak atau kurang melakukan budidaya jenis ubi jalar dan ubi kayu. Berdasarkan kondisi tersebut, maka dibutuhkan pasokan dari daerah atau wilayah di luar Kabupaten Jombang untuk mencukupi kebutuhan ubi jalar dan ubi kayu.

\section{KESIMPULAN}

Berdasarkan uraian hasil dan pembahasan yang diperoleh tersebut di atas, dapat disimpulkan yaitu:

1. Berdasarkan PDRB kabupaten Jombang menurut harga berlaku, subsektor tanaman pangan mengalami penurunan dari tahun 2014 sampai 2018 sebesar 1,95 persen.

2. Berdasarkan perhitungan LQ PDRB subsektor atas harga berlaku menurut lapangan usaha tahun 2014 - 2018 Kabupaten Jombang, tanaman pangan belum bisa di katakan basis karena mempunyai nilai rata-rata yaitu 0,96 .

3. Berdasarkan perhitungan analisis LQ pada tanaman pangan di setiap kecamatan, rata-rata hampir semua kecamatan lebih basis atau unggul pada pada 2 jenis tanaman pangan yaitu Jagung dan Padi.

\section{DAFTAR PUSTAKA}

BPS. 2018. Jombang Dalam Angka (2018) (Jombang In Figures 2018). BPS Kabupaten Jombang.

BPS. 2018. Jawa Timur Dalam Angka (2018) (Jawa Timur In Figures 2018). BPS Propinsi Jawa Timur.

Tanjung, I.P. 2017. Kontribusi Subsektor Perkebunan Terhadap Perekonomian Daerah : Studi Kasus di Provinsi Jawa Timur. Jurusan Ekonomi Pembangunan, Fakultas Ekonomi dan Bisnis Universitas Islam Negeri Syarif Hidayatullah Jakarta.

Produk Domestik Regional Bruto (PDRB) seri 2010 atas harga berlaku menurut sektor tahun 2014-2018 Kabupaten Jombang. 
Produk Domestik Regional Bruto (PDRB) seri 2010 atas harga berlaku menurut subsektor tahun 2014-2018 Kabupaten Jombang.

Produk Domestik Regional Bruto (PDRB) seri 2010 atas harga berlaku menurut sektor tahun 2014-2018 Provinsi Jawa Timur.

Produk Domestik Regional Bruto (PDRB) seri 2010 atas harga berlaku menurut subsektor tahun 2014-2018 Provinsi Jawa Timur.

Sofyan, Rakhmat. "Analisis Komoditas Unggulan Sektor Pertanian Di Kabupaten Pemalang”. Skripsi. Semarang: Fakultas Ilmu Sosial Universitas Negeri

Semarang. 2014

Hardyanto, "Analisis Komoditas unggulan sector pertanian di kabupaten Seluman Provinsi Bengkulu”. Skripsi. Bengkulu: Fakultas Ekonomi dan bisnis Universitas Bengkulu 2014. 